\title{
Kappa Opioids Inhibit Induction of Long-Term Potentiation in the Dentate Gyrus of the Guinea Pig Hippocampus
}

\author{
Gregory W. Terman, ${ }^{1,2}$ John J. Wagner, ${ }^{1, a}$ and Charles Chavkin ${ }^{1}$ \\ Departments of ${ }^{1}$ Pharmacology and ${ }^{2}$ Anesthesiology, University of Washington School of Medicine, Seattle, Washington \\ 98195
}

\begin{abstract}
NMDA receptor-mediated long-term potentiation (LTP) of dentate granule cell responses to perforant path stimulation was inhibited by the $\kappa_{1}$ opioid receptor agonist U69,593. This inhibition was reversed stereospecifically by naloxone and blocked by the selective $\kappa_{1}$ antagonist norbinaltorphimine (NBNI). NBNI, by itself, had no effect on LTP induced by threshold stimulation but significantly enhanced LTP from more prolonged stimulation. This effect of NBNI suggests that endogenous opioids can regulate LTP in the dentate gyrus. In support of this hypothesis, stimulation of dynorphin-containing fibers also blocked LTP production in an NBNI-sensitive manner. Finally, dynorphin-mediated inhibition of LTP acts primarily on mechanisms of induction rather than maintenance or expression, since dynorphin released immediately before, but not immediately after, perforant path stimulation blocked LTP. Thus, exogenous and endogenous $\kappa$ opioids can inhibit induction of long-term potentiation at the perforant path-granule cell synapse and may therefore regulate plastic changes in synaptic transmission in a brain region thought to play an important role in processes of both learning and memory and epileptogenesis.
\end{abstract}

[Key words: hippocampus, dentate gyrus, $x$ opioids, endogenous opioids, long-term potentiation, LTP induction]

High-frequency stimulation of excitatory neocortical (Lee, 1982), limbic (Racine et al., 1983), and hippocampal pathways (e.g., Bliss and Gardner-Medwin, 1973; Bliss and Collingridge, 1993) can produce long-lasting increases in responses to subsequent stimulation, a phenomenon known as long-term potentiation (LTP). Such LTP can persist for weeks beyond the initial stimulation (Bliss and Gardner-Medwin, 1973) and has been suggested to be a cellular basis for learning and memory (e.g., Bliss and Collingridge, 1993). LTP has been most extensively studied in the hippocampus, due in part to the role this region plays in learning and memory. In addition, the highly structured cytoarchitccturc of the hippocampus allows selective afferent stimulation in vivo and in vitro and facilitates study of the neurochemical mechanisms underlying LTP. From such studies,

\footnotetext{
Received July 22, 1993; revised Nov. 22, 1993; accepted Dec. 21, 1993.

This work was supported by grants from the USPHS (DA04123 and GM07604) and the Foundation for Anethesia Education and Research with a grant from Abbott Laboratories.

Correspondence should be addressed to Gregory Terman, M.D., Ph.D., Department of Anesthesiology, RN 10, University of Washington, Seattle, WA 98195.

a Present address: Department of Physiology, University of Maryland School of Medicine, Baltimore, MD 21201.

Copyright (C) 1994 Society for Neuroscience $0270-6474 / 94 / 144740-08 \$ 05.00 / 0$
}

glutamate has been found to act at NMDA (Harris et al., 1984; Wigstrom and Gustaffson, 1984; Morris et al.,1986; Morris, 1989) and non-NMDA (Grover and Teyler, 1990; Bashir et al., 1993) type receptors within the hippocampus to mediate LTP induction. Other putative neurotransmitters, including adenosine (Alzheimer et al., 1991), glycine (Bashir et al., 1990), GABA (Davies et al., 1991; Morrisett et al., 1991), acetylcholine (Williams and Johnston, 1988), norepinephrine (Hopkins and Johnston, 1984), dopamine (Frey et al., 1990), nitric oxide (Schuman and Madison, 1991), and arachidonic acid (Lynch et al,, 1991), have all also been reported to play a role in the neurochemical modulation of LTP.

Recently, opioid peptides and their receptors have incrcasingly been implicated in the control of LTP in the hippocampus (Martin, 1983; Bramham et al., 1988, 1991; Satoh et al., 1989; Ishihara et al., 1990; Derrick et al., 1991, 1992; Xie and Lewis, 1991; Bramham, 1992; Terman et al., 1992; Wagner et al., 1993; Weisskopf et al., 1993). The hippocampus is rich in $\mu, \delta$, and $\kappa$ opioid receptors (McLean et al., 1987; Zukin et al., 1988; Wagner et al., 1990, 1991) and contains the presumed natural ligands for these receptors, the enkephalins and dynorphins (Gall et al., 1981; McGinty et al., 1983, 1984; Weber and Barchas, 1983; Chavkin et al., 1985; Crain et al., 1986). The dentate granule cells, for example, contain mRNA for both proenkephalin and prodynorphin and receive afferent input from the entorhinal cortex by way of proenkephalin-containing perforant path fibers (Chavkin et al., 1985). The dentate molecular layer, containing perforant path axon terminals (among other afferent inputs), granule cell dendrites, and numerous interneurons, contains $\mu$, $\delta$, and $\kappa$ binding sites (McLean et al., 1987). In the rat dentate gyrus, $\mu$ (Xie and Lewis, 1991) and $\delta$ (Bramham et al., 1991) opioid antagonists have been reported to block the production of LTP. This is consistent with numerous reports of disinhibitory effects of $\mu$ and $\delta$ opioids on neurotransmission within the hippocampus (e.g., Zieglgansberger et al., 1979; Lee et al., 1980; Masukawa and Prince, 1982).

In contrast, we have recently reported that $\kappa$ opioid agonists have principally inhibitory effects in the guinea pig dentate gyrus (Wagner et al., 1992). Both dynorphin B and the $\kappa_{1}$-specific agonist $U 69,593$ produce an inhibition of perforant path-stimulated granule cell activity that is blocked by the $\kappa_{1}$-selective (Nock et al., 1988, 1990; Takemori et al., 1988) opioid antagonist norbinaltorphimine (NBNI) (Wagner et al., 1992). A presynaptic, rather than a postsynaptic, site of action for this $\kappa$ receptor-mediated inhibition was suggested by (1) the lack of effect of $k$ opioids on granule cell resting potentials and membrane conductances using intracellular (Wagner et al., 1992) and whole-cell voltage clamp (Wagner et al., 1993) techniques, and 
(2) the lack of inhibitory effects on GABA-mediated IPSPs (Wagner et al., 1992) or commissural/associational glutamatemediated EPSCs (Wagner et al., 1993). The inhibitory effects of $\kappa$ opioids on synaptic transmission in the dentate gyrus led us to examine the effects of these opioids on LTP and the longlasting excitatory changes underlying this phenomenon.

\section{Materials and Methods}

Electrophysiological preparation. As previously described (Wagner et al., 1992), adult male 175-250 gm Hartley guinea pigs (Simonsen Laboratories, Gilroy, CA) were decapitated and the brains quickly removed, cooled, blocked, and cut using a Vibratome (Technical Products International) into $600 \mu \mathrm{m}$ sections. Hippocampal slices were transferred to a warmed $\left(34^{\circ} \mathrm{C}\right)$ submerged tissue recording chamber and were perfused at $1 \mathrm{ml} / \mathrm{min}$ with modified artificial cerebrospinal fluid $(125 \mathrm{~mm} \mathrm{NaCl}$, $3 \mathrm{~mm} \mathrm{KCl}, 4 \mathrm{~mm} \mathrm{CaCl}, 4 \mathrm{~mm} \mathrm{MgCl}, 1.25 \mathrm{~mm} \mathrm{NaH} \mathrm{PO}_{4}, 26 \mathrm{~mm}$ $\mathrm{NaHCO}_{3}, 10 \mathrm{~mm}$ glucose, and $10 \mu \mathrm{M}$ bicuculline). After an hour of equilibration, a $100 \mu \mathrm{m}$ concentric bipolar electrode was placed in the outer molecular layer of the dentate gyrus (Fig. 1A) and was used to stimulate perforant path fibers with $0.3 \mathrm{msec}$ square-wave pulses of $25-$ $300 \mu \mathrm{A}$. A glass recording electrode (1-2 $\mu \mathrm{m}$ tip) filled with $3 \mathrm{M} \mathrm{NaCl}$ was placed in the granule cell layer of the dentate gyrus (Fig. $1 . A$ ) using a dissection microscope. A digitizing oscilloscope (5DI0 Tektronix, Beaverton, $O R$ ) was used to measure stimulus-evoked peak-to-peak population response amplitudes (c.g., Fig. $1 B$, inset), and the recording electrode was advanced to maximize these responses. In certain experiments, a $100 \mu \mathrm{m}$ concentric bipolar electrode was also placed in the hilus of the hippocampus (Fig. $1 A$ ).

Quantitation of responses. An initial stimulus/response curve was determined for granule cell excitation from perforant path stimulation (e.g., Fig. 2). Stimuli of increasing intensity were given at $1 \mathrm{~min}$ intervals to the perforant path and granule cell population response (spike) amplitudes recorded. The stimulus intensity that evoked a half-maximal granule cell population spike amplitude, $S_{1 / 2}$ (e.g., Fig. 2), was chosen for subsequent test stimuli. $S_{1 / 2}$ test pulses were then given at $1 \mathrm{~min}$ intervals throughout the experimental period. Prior to each new tetanic stimulation or drug addition, the stimulus intensity for the test pulse was adjusted to continue evoking a half-maximal $\left(S_{1 / 2}\right)$ response, and at least five baseline test pulses were given. Thus, changes in responsiveness produced by experimental manipulations were based on changes from the baseline measures determined immediately prior to each manipulation. In a subset of experiments, slope of the initial rising segment of the population spike (extracellular EPSP slope) was concurrently measured.

Perforant path high-frequency stimulation was applied using the molecular layer stimulating electrode and consisted of three $100 \mathrm{~Hz}$ trains of $0.3 \mathrm{msec} 300 \mu \mathrm{A}$ pulses, given one train every $10 \mathrm{sec}$ (train duration varied as a function of the particular experiment) (e.g., Fig. 1C). Hilar high-frequency stimulation consisted of six $1 \mathrm{sec} 50 \mathrm{~Hz}$ trains of 0.3 $\mathrm{msec} 300 \mu \mathrm{A}$ pulses, given one train every $10 \mathrm{sec}$ by way of the stimulating electrode in the hilus. Long-term potentiation was operationally defined as the mean change in population spike amplitude or EPSP slope response to five test pulscs given bcginning 30 min after perforant path tetanic stimulation compared with the mean response to five test pulses given immediately prior to the tetanus (e.g., Fig. $1 B$ ).

Drug effects were studied at equilibrium from 15 to $20 \mathrm{~min}$ after addition of drug to the artificial cerebrospinal fluid perfusate. Mean granule cell population spike amplitude or EPSP slope responses to five perforant path test pulses (at $S_{1 / 2}$ ) given immediately prior to drug application were compared with the mean response to five test pulses of the same intensity given beginning 15 min postdrug. Data were transformed to percentage of spike amplitude or EPSP slope change (e.g., percentage spike amplitude change $=$ (postdrug - predrug mean amplitude/predrug mean amplitude) and statistically analyzed using between-subjects and/or within-subjects analyses of variance as appropriate with Tukey's tests for between group post hoc comparisons (Hays, 1973). A probability of $<0.05$ was chosen for statistically significant rejection of the null hypothesis.

Materials. Bicuculline, U69,593, (-)naloxone and D-2-amino-5phosphonovalerate (APV) were purchased from Sigma Chemical. Norbinaltorphimine was purchased from Research Biochemicals Incorporated. (+)Naloxone was a gift from NIDA. All drugs were added to the perfusate in a $1: 1000$ dilution.

\section{Results}

The $\kappa$ agonist U69,593 ( $1 \mu \mathrm{M})$ significantly inhibited dentate granule cell population spike amplitude evoked by perforant path stimulation (by $46 \pm 5 \%$ from predrug values at $S_{1 / 2} ; n=$ 12) (e.g., Fig. 2) compared to controls exposed to no drug $(0.5$ $\pm 0.2 \%$ change after $15 \mathrm{~min} ; n=12$ ). This inhibition was blocked by adding either $1 \mu_{\mathrm{M}}(-)$ naloxone $(-2 \pm 6 \%$ of predrug control; $n=6$ ) (e.g., Fig. 2) or 100 nm norbinaltorphimine (NBNI) ( $3 \pm 3 \%$ of predrug control; $n=6$ ) to the U69,593 perfusing the slice. Results from a representative experiment are shown in Figure 2. Neither opioid antagonist, by itself, significantly affected population spike amplitudes $(9 \pm 8 \%$ and -2 $\pm 4 \%$ changes, respectively; $n=7$ and 22). Moreover, U69,593 significantly decreased the slope of the population spike EPSP after $15 \mathrm{~min}$ (by $23.6 \pm 6 \%$ ) compared to controls not exposed to any drug (increased by $0.25 \pm 2 \%$ ). These data replicate and extend our previous work (Wagner et al., 1992) demonstrating $\kappa$ receptor-mediated inhibition of perforant path-induced granule cell excitation.

As shown in Figure $1 B$, LTP could be produced by a moderate tetanus to the perforant path (three $20 \mathrm{msec}$ trains of $100 \mathrm{~Hz}$ pulses given one train every $10 \mathrm{sec}$ ). In accordance with the findings of others (e.g., Harris et al., 1984; Wigstrom and Gustaffson, 1984; Morris et al., 1986), the NMDA glutamate receptor antagonist D-2-amino-5-phosphonovaleric acid (APV) $(50 \mu \mathrm{M})$ applied to the perfusate prior to tetanic stimulation blocked LTP production (Fig. $3 A$ ) without significantly affecting the population response amplitude to test stimuli. U69,593 (1 $\mu \mathrm{M}$ ) also blocked LTP production (Fig. 3A), and the effect of U69,593 was reversed when these slices were stimulated again in the presence of the opioid antagonist (-)naloxone (Fig. $3 B$ ). In contrast, the opioid receptor-inactive stereoisomer (Caudle et al., 1991), (+)naloxone was ineffective in reversing the LTPinhibiting effects of U69,593 (Fig. 3B). In addition, the LTP of the EPSP slope caused by perforant path tetanus was blocked by $U 69,593$ in a naloxone-sensitive fashion (Fig. $3 C$ ). The inhibitory effects of U69,593 on LTP were also blocked by coadministration of the $\kappa_{1}$-selective antagonist norbinaltorphimine (100 nM) (NBNI) with the $\kappa$ agonist (Fig. 3A). However, this opiatc antagonist had no significant effect on LTP (Fig. $4 B$ ) when given alone under these conditions (see also Hanse and Gustafsson, 1992). These results indicate that activation of $\kappa_{1}$ opioid receptors can block LTP production in the guinea pig dentate gyrus.

During our initial characterization of stimulation paradigms effective in producing LTP, we examined the effects of varying perforant path tetanic stimulus duration on the magnitude of LTP produced. Each slice was exposed to only a single tetanus paradigm. Tetani consisted of $100 \mathrm{~Hz}$ trains given three times at $10 \mathrm{sec}$ intervals as above (Fig. 1C). Tetani of 20, 50, 100, and 500 msec durations produced significant increases in population spike amplitudes measured 30 min posttetanus when compared to nontetanized controls-producing potentiation of $48 \%, 115 \%, 123 \%$, and $43 \%$, respectively (Fig. $4 A$ ). As expected, longer tetani produced generally greater potentiation, attaining a similar LTP maximum magnitude after 50 and $100 \mathrm{msec}$ tetani. This result is in keeping with the well-described phenomenon of LTP saturation (Huang and Malenka, 1993). Surprisingly, however, the $500 \mathrm{msec}$ tetanus produced significantly less LTP than the $100 \mathrm{msec}$ tetanus (Fig. $4 \mathrm{~A}$ ). In our next study, we examined if there was a relationship between the observed 
A

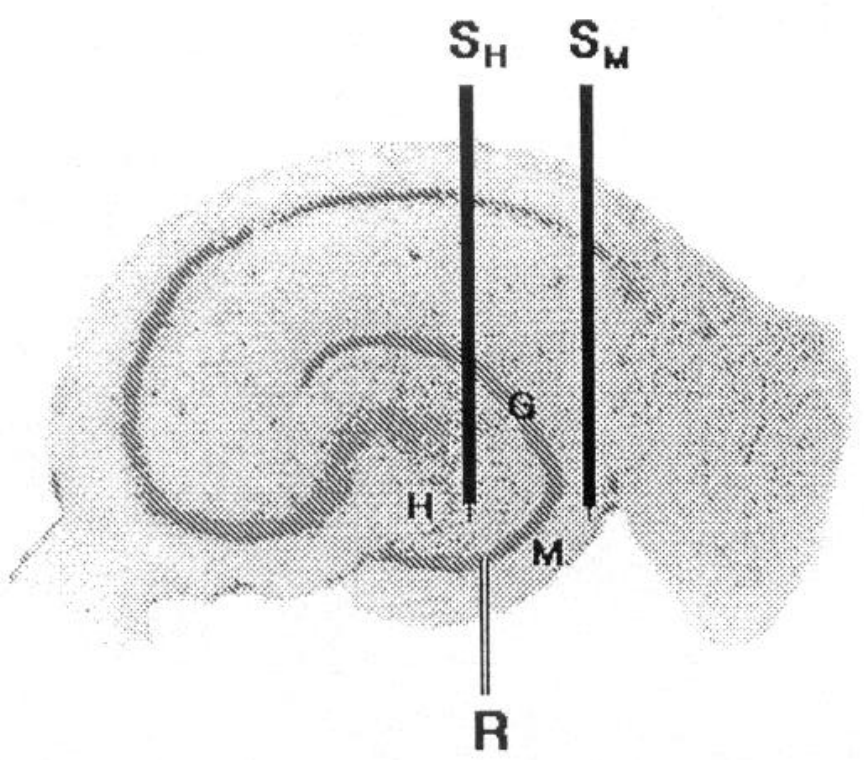

B

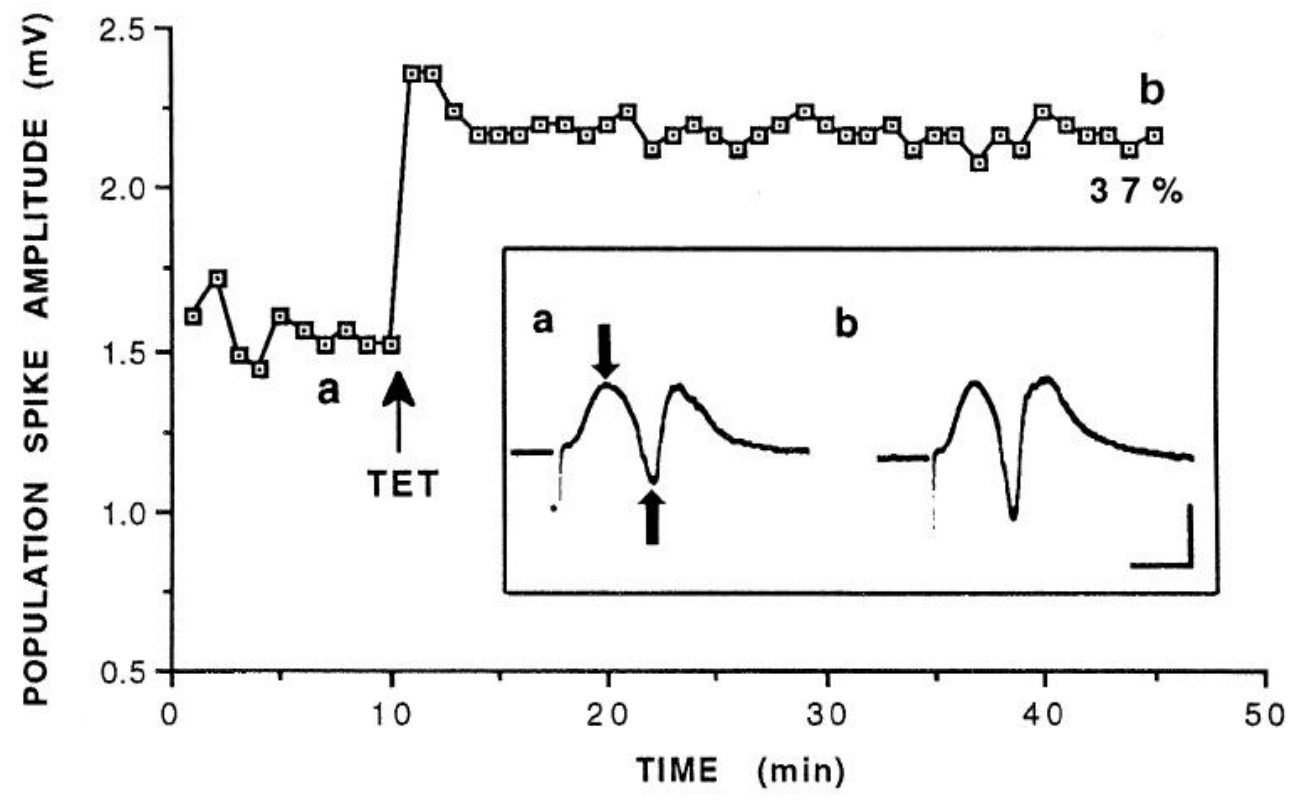

\section{0 mS 100 hz PERforant Path tethnUS}

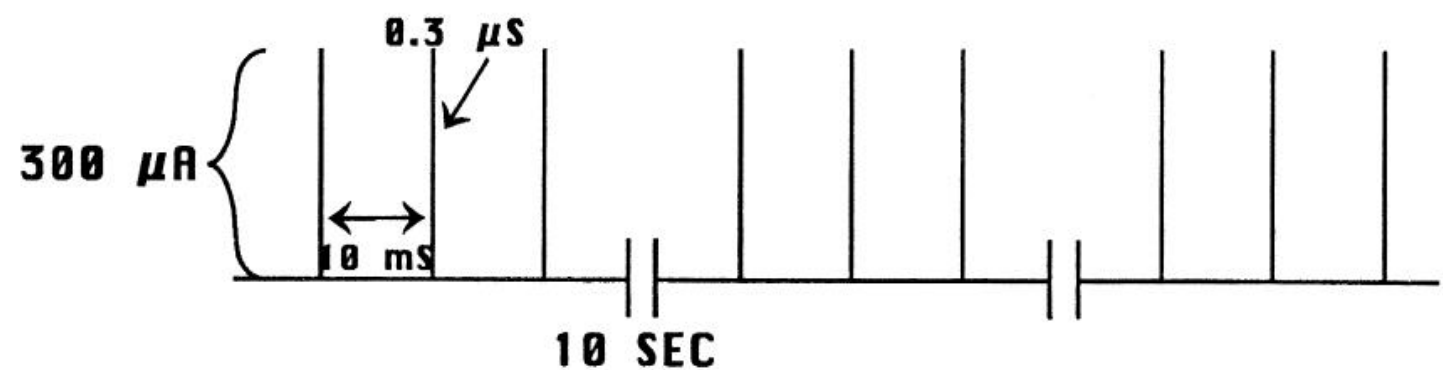

Figure 1. A, Digitally scanned cresyl violet-stained guinea pig hippocampal slice with schematic representations of the recording and stimulating electrode sites used in our studies. The recording electrode $(R)$ was placed in the granule cell layer $(G)$ of the dentate gyrus. One stimulating electrode $\left(S_{M}\right)$ was placed in the outer dentate molecular layer $(M)$ and in certain experiments a second stimulating electrode $\left(S_{H}\right)$ was placed in the hilus 


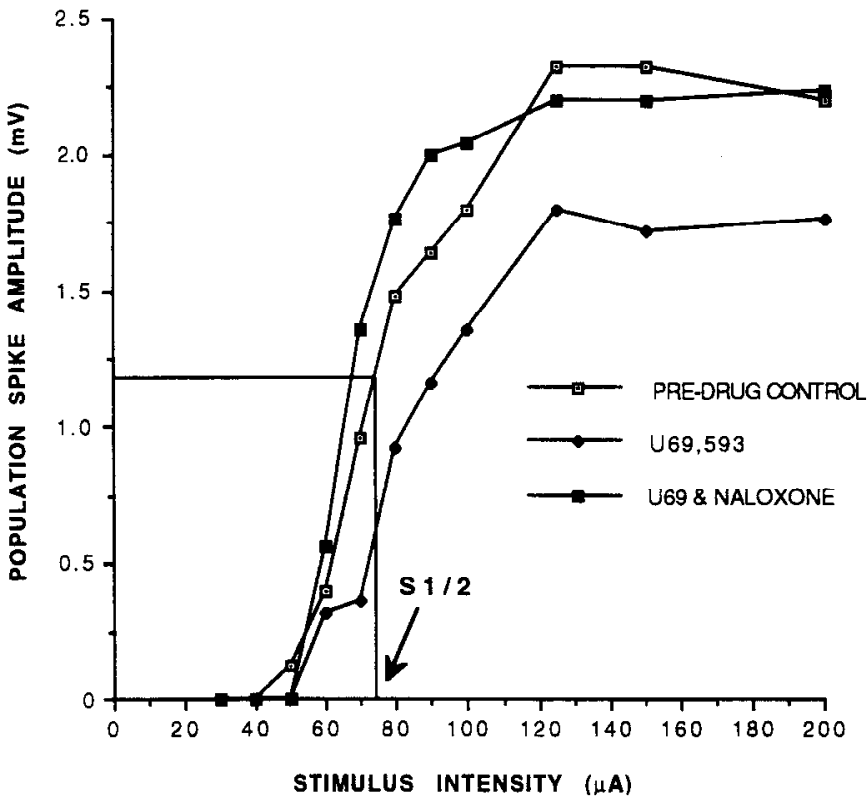

Figure 2. Representative example of the inhibitory effect of $U 69,593$ on population spike amplitude. Stimuli of various intensities were given at 1 min intervals to the perforant path and the granule cell population spike amplitudes recorded. The stimulus intensity that evoked a halfmaximal granule cell population spike amplitude, $S_{\mathrm{b} / 2}$, was chosen for subsequent test stimuli, and percentage change data were derived from responses to this intensity. In this example, $15 \mathrm{~min}$ after U69,593 (1 $\mu_{\mathrm{M}}$ ) was added to the perfusate, population spike response amplitudes were decreased across all stimulus intensities $(U 69,593)$ from predrug control values. Coadministration of naloxone $(1 \mu \mathrm{M})$ with $\mathrm{U} 69,593$ for $15 \min (U 69 \& N A L O X O N E)$ reversed the inhibition.

inhibition of LTP production by $\kappa$ receptor activation and the reduced magnitude of LTP produced by supramaximal tetanic stimulation.

We have previously reported that high-frequency stimulation of the perforant path can release endogenous opioids (Wagner et al., 1990, 1991). We tested whether the reduction in LTP magnitude following longer-duration tetani might be sensitive to opioid receptor antagonism. Whereas NBNI (100 nm) had no significant effect on LTP from either the $20 \mathrm{msec}$ or 100 msec stimulation paradigms (Fig. $4 B$ ), this antagonist did produce a significant increase in LTP elicited from the $500 \mathrm{msec}$ perforant path stimulation (Fig. $4 B$ ). This suggests that an endogenous opioid agonist is relcased by the $500 \mathrm{msec}$ stimulation. $\kappa_{1}$ receptor activation by this endogenous opioid appears capable of decreasing LTP production just as is seen with U69,593 application.

To determine whether $\kappa$ opioids influence LTP production by primarily affecting induction, maintenance, or expression of LTP, we turned to another paradigm of endogenous $k$ opioid release that we have been studying concurrently. Tetanic stimulation of the mossy fibers in the hilus at $50 \mathrm{~Hz}$ for $1 \mathrm{sec}$ produces a release of dynorphin from dentate granule cells (Wagner et al., 1991). In the present study, we used this brief and reproducible
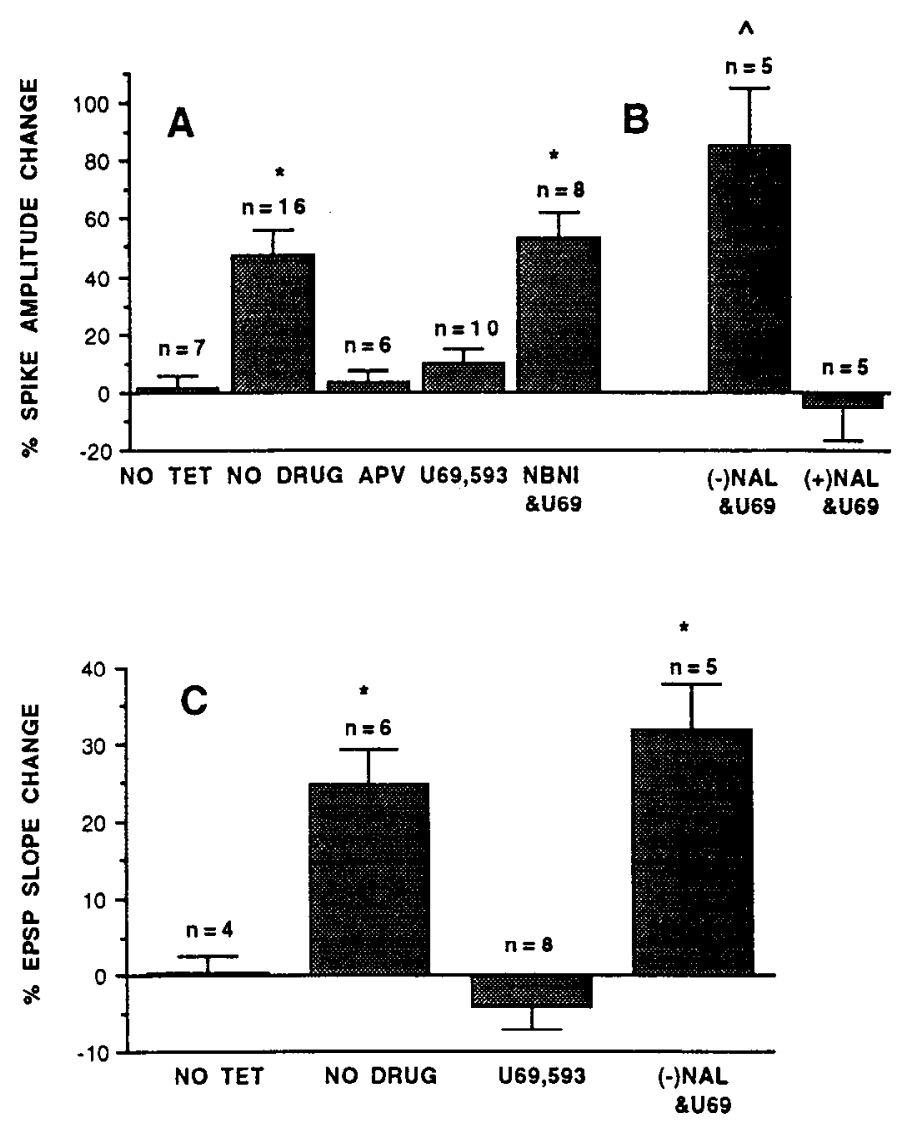

Figure 3. A, Blockade of NMDA receptor-dependent long-term potentiation (LTP) by $\kappa$ receptor activation. LTP, defined as the increase in population spike amplitude $30 \mathrm{~min}$ following a $20 \mathrm{msec} 100 \mathrm{~Hz}$ perforant path tetanus (NO DRUG), was blocked both by the NMDA receptor antagonist APV $(50 \mu \mathrm{M})$ and by the $\kappa_{1}$ opioid receptor agonist U69,593 $(1 \mu \mathrm{M})$. The inhibition of LTP by U69,593 was blocked by coadministration of $100 \mathrm{nM}$ of norbinaltorphimine $(N B N I)$ with the $\kappa$ agonist. *, significant $(p<0.05)$ difference from controls receiving no tetanus (NOTET), which were simply tested for population spike amplitude stability for $30 \mathrm{~min} . n=$ number of slices studied. $B$, Naloxone stereospecifically reverses the $\kappa$ opioid blockade of LTP. Slices exposed to $\mathrm{U} 69,593$ in $A$ were then perfused with $1 \mu \mathrm{M}$ of either the opioid antagonist ( - )naloxone or its opioid-inactive stereoisomer $(+)$ naloxone and given a second perforant path tetanus. Whereas a second $20 \mathrm{msec}$ perforant path tetanus still produced no LTP in the $(+)$ naloxone group [(+)NAL\&U69], (-)naloxone reversed the LTP blocking effects of U69,593 [(-)NAL\&U69]. $\wedge$, significant $(p<0.05)$ difference from U69,593 results in $A . n=$ number of slices studied. $C$, LTP of the slope of the extracellular EPSP initial segment recorded in the granule cell layer $(N O D R U G)$ is blocked by $\mathrm{U} 69,593(1 \mu \mathrm{M})$ alone $(U 69,593)$, but not when coadministered with $(-)$ naloxone $(1 \mu \mathrm{M})[(-) N A L \& U 69] .{ }^{*}$, significant $(p<0.05)$ difference from nontetanized (NOTET) controls. $n=$ number of slices studied.

method of endogenous $\kappa$ opioid release to compare the effects of $\kappa$ opioids released immediately before versus immediately after perforant path stimulation $(20 \mathrm{msec} 100 \mathrm{~Hz}$ tetanus) induced LTP. As previously reported (Wagner et al., 1993), hilar tetanic stimulation blocked LTP production in an NBNI-sen-

$(H) . B$. Example of LTP of the dentate granule cell population (spike) response to perforant path stimulation. Although initially stable, population spike amplitude showed a rapid and persistent potentiation following a $20 \mathrm{msec} 100 \mathrm{~Hz}$ perforant path tetanic stimulus (TET) (as in C), showing a $37 \%$ increase 30 min posttetanus. Inset, Representative oscilloscope tracings of population responses before $(a)$ and after $(b)$ LTP induction (TET). Population spike amplitude was measured peak to peak as indicated (arrows). Calibration: $1 \mathrm{mV}, 5 \mathrm{msec}$. $C$, Schematic of the $20 \mathrm{msec} 100$ $\mathrm{Hz}$ perforant path tetanic stimulation paradigm used to produce LTP in the majority of the present studies. 
A

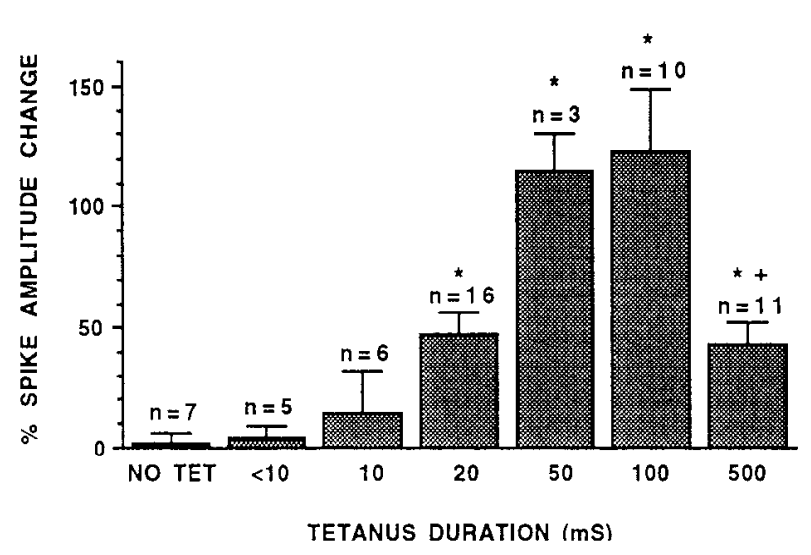

B

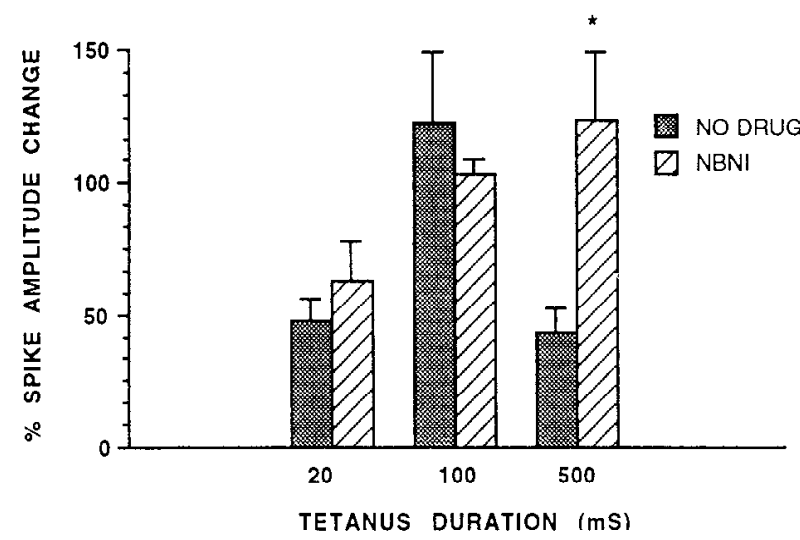

Figure 4. A, Parametric evaluation of dentate granule cell population spike amplitude LTP produced by various durations of perforant path tetanic stimulation. Tetani consisted of three $100 \mathrm{~Hz}$ trains of $0.3 \mu \mathrm{sec}$ $300 \mu \mathrm{A}$ pulses given one train every $10 \mathrm{sec}$ (e.g., Fig. $1 C$ ). Tetani of 20 , 50,100 , and $500 \mathrm{msec}$ produced significant LTP. ${ }^{*}$, significant $(p<$ $0.05)$ difference from nontetanized (NO TET) controls. In general, longer-duration tetani produced greater potentiation except for the 500 msec tetanus, which produced significantly $(p<0.05)$ less LTP than the 100 msec tetanus. + , significant $(p<0.05)$ difference between the $500 \mathrm{msec}$ and $100 \mathrm{msec}$ groups). Each slice was tetanized only once. $n$ $=$ number of slices studied. $B$, NBNI $(100 \mathrm{~nm})$ has no effect on LTP from $20 \mathrm{msec}$ or $100 \mathrm{msec}$ tetanic stimulation but enhances LTP from 500 msec of tetanic stimulation. For ease of presentation, NO DRUG data is repeated from $A .{ }^{*}$, significant $(p<0.05)$ difference from NO DRUG controls. Eight different slices were studied in each of the NBNI groups.

sitive manner when given immediately prior to perforant path stimulation (Fig. 5A,B). However, when hilar stimulation immediately followed perforant path tetanic stimulation, there was no significant decrease in LTP compared to slices not receiving hilar stimulation (Fig. $5 B$ ). These findings suggest that $\kappa$ opioids are having their primary effect on LTP by inhibiting induction mechanisms. If maintenance or expression mechanisms of LTP were primarily inhibited by $\kappa$ opioids, then release of these peptides pre- or postinduction would be expected to block LTP to a similar degree.

\section{Discussion}

The principal finding of this study is that both pharmacologically applied and endogenously released $\kappa$ opioids modulate the response of dentate granule cells to high-frequency stimulation of

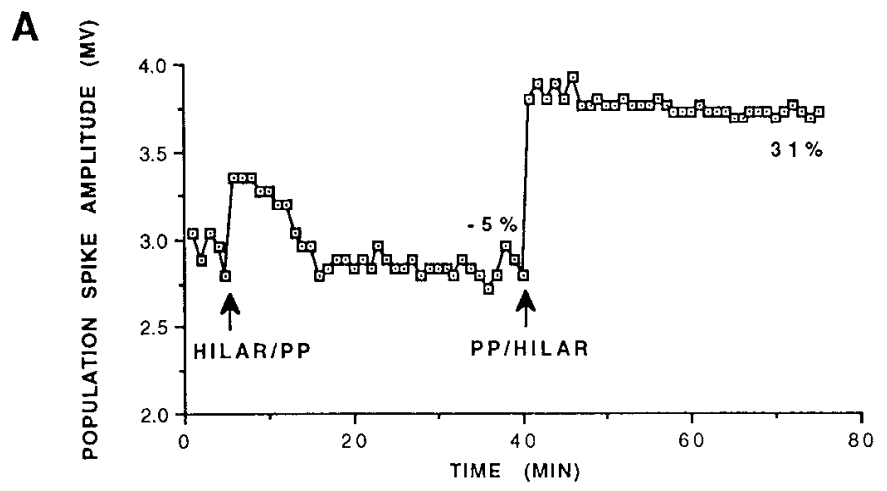

B

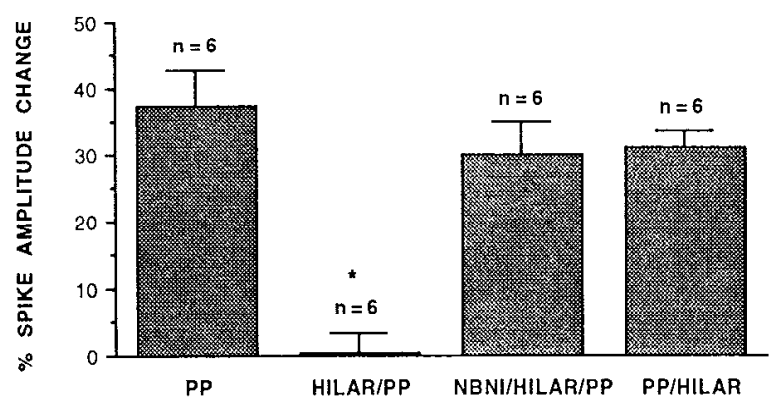

Figure 5. A, Representative example of blockade of LTP by hilar stimulation given immediately before $(H I L A R / P P)$ but not immediately after $(P P / H I L A R) 20 \mathrm{msec}$ of $100 \mathrm{~Hz}$ perforant path stimulation. Hilar stimulation consisted of six $1 \mathrm{sec}$ trains of $50 \mathrm{~Hz} 300 \mu \mathrm{A}$ pulses given one train of every $10 \mathrm{sec}$. Whereas $30 \mathrm{~min}$ after PP/HILAR stimulation mean population spike amplitude was increased by $31 \%, 30 \mathrm{~min}$ after HILAR/PP stimulus pairing produced a $5 \%$ decrement in spike amplitude. The short-term potentiation shown here when hilar stimulation preceded perforant path tetanic stimulation was seen for various durations in about half the slices tested but never lasted more than 10 min. $B$, A series of replicates showing that LTP $30 \mathrm{~min}$ after perforant path tetanic stimulation is inhibited by hilar stimulation given immediately before (IILLAR/PP) but not immediately after (PP/HILAR) perforant path tetani. This inhibition is blocked by $15 \mathrm{~min}$ of pretreatment with NBNI $(100 \mathrm{~nm})(N B N I / H I L A R / P P) .{ }^{*}$, significant $(p<0.05)$ difference from controls receiving perforant path tetanic stimulation without hilar stimulation $(P P), n=$ number of slices studicd.

the perforant path. This was evident as two distinct effects on long-term potentiation at this synapse. First, consistent with our previous findings in which endogenous dynorphins were found to block LTP induction (Wagner et al., 1993), we show here that $\kappa_{1}$ receptor activation by U69,593 is also able to block LTP. We have extended our previous work concerning released endogenous opioids by demonstrating that the block of LTP (measured at $30 \mathrm{~min}$ posttetanus) is duc to a $\kappa$ receptor-mediated inhibition of the induction process, and not due to inhibition or masking of LTP expression. Second, we have described conditions in which biphasic, homosynaptic modulation of resulting LTP magnitude can occur, and have provided evidence indicating that endogenous dynorphin release is likely to underlie this phenomenon.

The studies here were all performed in the presence of the GABA antagonist bicuculline. Thus, in contrast with numerous reports describing an inhibition of $\mathrm{GABA}_{\mathrm{A}}$ release by other (i.e., non- $\kappa_{1}$ ) opiate agonists (Zieglgansberger et al., 1979; Lee et al., 1980; Masukawa and Prince, 1982; Neumaier et al., 1988), the effects ascribed here to $\kappa$, receptor activation are not mediated 
by altering GABA release. Instead, in agreement with our previous work (Wagner et al., 1992, 1993), we propose that the effects of $\kappa_{1}$ receptor activation involve a presynaptic inhibition of glutamate release from perforant path terminals. In addition to the antagonistic actions of the $\kappa$ opioid antagonist norbinaltorphimine, the stereospecific reversal of U69,593 effects by naloxone provides strong pharmacologic evidence that the described effects are in fact due to opioid receptor activation.

In our experimental preparation (i.e., the guinea pig perforant path-dentate granule cell synapse in the presence of bicuculline) tetanus-induced LTP was APV sensitive (see also Hanse and Gustafsson, 1992). The ability of $\kappa_{1}$ receptor activation to inhibit LTP via a depression of glutamate release fits well with the current model for NMDA receptor-mediated induction of LTP (for review, see Bliss and Collingridge, 1993). Although it has been shown that activation of CNQX-sensitive receptors is not required for the induction of LTP (Kauer et al., 1988; Muller et al., 1988), a threshold level of postsynaptic depolarization must be reached to allow $\mathrm{Ca}^{2+}$ influx through the NMDA receptor (e.g., Bliss and Collingridge, 1993). The recent report (Bashir et al., 1993) demonstrating that metabotropic glutamate receptor activation is required for APV-sensitive LTP also would be in agreement with this mechanism for $\kappa$ opioid action. By reducing the release of glutamate presynaptically, transmitter actions at all types of glutamate receptors would be decreased, resulting in a subthreshold stimulus for the generation of LTP.

A trivial explanation for the inhibition of LTP by U69,593 might have been that the granule cell response was so depressed by this drug that the measurement of LTP was obscured. This was not the case, as the test pulse stimulus intensity was readjusted in the presence of $\kappa$ opioids to elicit responses comparable to those seen in the predrug period. Our finding that LTP is inhibited by a transient release of endogenous dynorphins underscores this point. Initiation of hilar stimulation 1 min prior to perforant path tetanus was effective in blocking LTP, whereas when this dynorphin-releasing paradigm was bcgun immcdiately after the tetanus, it was without effect on LTP. This result clearly indicates that dynorphin's LTP inhibitory effects are due primarily to an interference with early (within a minute of tetanus onset) induction processes rather than disrupting mechanisms of LTP maintenance or masking LTP expression $30 \mathrm{~min}$ later.

Our observation that the 500 msec duration of a $100 \mathrm{~Hz}$ tetanus yielded significantly less LTP $30 \mathrm{~min}$ posttetanus than did a $100 \mathrm{msec}$ tetanus was surprising to us. Obviously, these studies were not designed to evaluate systematically the relative importance of various stimulus parameters (i.e., intensity, frequency, duration, or number) on elicited LTP magnitude. Nonetheless, we are unaware of any previous reports in which longer or more numerous tetanic stimuli (of the same frequency) resulted in a significant decrement in the magnitude of the resulting LTP. As up to $1 \mathrm{sec}$ of $100 \mathrm{~Hz}$ stimulation is a common stimulus in LTP studies, the biphasic phenomenon reported here is unlikely to be due to a stimulation-induced lesion of the perforant path. Indeed, the reduced LTP magnitude following the $500 \mathrm{msec}$ tetanus was completely reversed in the presence of NBNI. The implication of this finding is that endogenous dynorphin released during the $500 \mathrm{msec}$ perforant path train acts to inhibit LTP partially. In support of this hypothesis, we have previously demonstrated that high-frequency stimulation in the molecular layer can release endogenous dynorphin as measured in a neurochemical slice binding assay (Wagner et al.,
1991). In that study, a granule cell source for the released dynorphin was suggested by the finding that release from molecular layer stimulation but not hilar stimulation was inhibited by blockade of perforant path-granule cell excitatory neurotransmission by CNQX. Recently, we have identified, using immunohistochemical techniques at the electron microscopic level, dynorphin-containing dense-core vesicles within molecular layer axons and dendrites (Drake et al., in press) in addition to their previously described hilar sources (McLean et al., 1987). The finding that endogenous dynorphin's inhibitory effects occur within a few seconds of hilar stimulation onset (Drake et al., in press) suggests that these local sources of dynorphin may be responsible for these effects.

Regardless of the specific source of dynorphin responsible for the endogenous opioid effects reported here, our data clearly support the hypothesis that dynorphins released from granule cells in the dentate by high-frequency afferent stimulation can act as a retrograde transmitter to feedback and inhibit responses to further afferent input. In this way, dynorphin appears uniquely situated to modulate neurotransmission, synaptic plasticity, and perhaps memory encoding within the hippocampal formation. In this regard, exogenous opioids are well known to inhibit learning and memory in a variety of in vivo paradigms (for review, see McGaugh, 1989). Endogenous opioids have also been implicated in such an inhibition, in that opioid antagonists have been found to facilitate learning (Messing et al., 1979; Gallagher et al., 1983, 1985). Elevated levels of dynorphin have been correlated with impaired spatial learning in aged rats (Jiang et al., 1989), an impairment found to be attenuated by naloxone (Gallagher et al., 1985). Finally, a naloxone-sensitive learning deficit is produced by dentate granule cell axonal stimulation (Collier and Routenberg, 1984), similar to the hilar stimulation that in our studies produced dynorphin release and inhibition of LTP induction.

In considering the functional aspects of dynorphin action in the dentate gyrus, it is interesting to compare our findings with those of others studying opioid regulation of synaptic physiology in this region. For example, Bramham et al. (1991) and Xie and Lewis (1991) have reported that endogenous opioids acting at $\delta$ and $\mu$ receptors, respectively, have facilitatory effects on LTP generation in the dentate gyrus of rats. Since the activation of these types of opioid receptors has been linked to an inhibition of GABA release from hippocampal interneurons, such disinhibition may explain the LTP-facilitating effects of $\mu$ and $\delta$ opioids, just as has been reported with the $\mathrm{GABA}_{\mathrm{A}}$ antagonists (Wigstrom and Gustafsson, 1985; Hanse and Gustafsson, 1992). In the studies reported here, we added bicuculline to the perfusate in an effort to eliminate possible $k$ opioid effects on GABAergic interneurons as a mechanism for our results. $\mu$ and $\delta$ opioid receptor-mediated disinhibition may also explain the epileptogenic effects seen with central administration of these opioid agonists (e.g., Tortella, 1988). In contrast, dynorphin's inhibitory feedback effects in the dentate gyrus may provide a mechanism to avoid pathological consequences of hyperexcitation in this region, including seizure production and cell death. $\kappa$ agonists, for example, have been reported to inhibit seizure activity in a variety of animal models (Tortella et al., 1986, 1990; Tortella, 1988) and have been found to be neuroprotective in ischemic brain (Birch et al., 1991). In one study (Singh et al., 1990), a $\kappa$ agonist was reported to stereospecifically block NMDA-induced seizures in an NBNI-sensitive manner via presynaptic $k$ receptors. Furthermore, mossy fiber stimulation, sim- 
ilar to our hilar stimulation paradigm, has been reported to cause a naloxone-reversible seizure threshold elevation in one seizure model (Jones, 1991). Finally, in epileptic patients, seizure activity has been correlated with increases in dynorphin-like immunoreactivity and mossy fiber sprouting (Houser et al., 1990). This proliferation of granule cell axons extending from the hilus back to the molecular layer has been associated in animal models with an increase in recurrent inhibition (Cronin et al., 1992; Sloviter, 1992) and may represent a structural adaptation to enhance dynorphin's negative feedback potential. In sum, dynorphin, by providing feedback control of afferent input to the hippocampus, may normally act to modulate hippocampal activity between adaptive levels of excitation involved in learning and pathological levels of excitation resulting in seizures and cell death.

\section{References}

Alzheimer C, Rohrenbe J, Tenbrugg G (1991) Adenosine depresses induction of LTP of the mossy fiber-CA3 synapse in vitro. Brain Res 543:163-165.

Bashir ZI, Tam B, Collingridge GL (1990) Activation of the glycine site in the NMDA receptor is necessary for the induction of LTP. Neurosci Lett 108:261-263.

Bashir ZI,-Bortolotto ZA, Davies CA, Berretta N, Irving AJ, Seal AJ, IIenley JM, Jane DE, Watkins JC, Collingridge GL (1993) Induction of LTP in the hippocampus needs synaptic activation of glutamate metabotropic receptors. Nature 363:347-350.

Birch PJ, Rogers H, Hayes AG, Hayward NJ, Tyers MB, Scopes DIC, Naylor A, Judd DB (1991) Neuroprotective actions of GR89696, a highly potent and selective $k$-opioid receptor agonist. Br J Pharmacol 103:1819-1823.

Bliss TVP, Collingridge GL (1993) A synaptic model of memory: longterm potentiation in the hippocampus. Nature 361:31-39.

Bliss TVP, Gardner-Medwin AR (1973) Long-lasting potentiation of synaptic transmission in the dentate area of the unanesthetized rabbit following stimulation of the perforant pathway. J Physiol (Lond) 232: $357-374$.

Bramham CR (1992) Opioid receptor dependent long-term potentiation: peptidergic regulation of synaptic plasticity in the hippocampus. Neurochem Int 20:441-448.

Bramham CR, Errington ML, Bliss TVP (1988) Naloxone blocks the induction of long-term potentiation in the lateral but not in the medial perforant pathway in the anesthetized rat. Brain Res 449:352-356.

Bramham CR, Milgram N, Srebo B (1991) Opioid receptor activation is required to induce LTP of synaptic transmission in the lateral perforant path in vivo. Brain Res 567:42-50.

Caudle RM, Wagner JJ. Chavkin C (1991) Endogenous opioids released from perforant path modulate norepinephrine actions and inhibitory postsynaptic potentials in guinea pig CA3 pyramidal cells. $\mathrm{J}$ Pharmacol Exp Ther 258:18-26.

Chavkin C, Shoemaker WJ, McGinty JF, Bayon A, Bloom FE (1985) Characterization of the prodynorphin and proenkephalin systems in rat hippocampus. J Neurosci 5:808-816.

Collier TJ, Routtenberg A (1984) Selective memory impairment of declarative memory following stimulation of dentate gyrus granule cells: a naloxone-sensitive effect. Brain Res 310:384-387.

Crain BJ, Chang KJ, McNamara JO (1986) Quantitative autoradiographic analysis of mu and delta opioid binding sites in the rat hippocampal formation. J Comp Neurol 246:170-180.

Cronin J, Obenaus A, Houser CR, Dudek FE (1992) Electrophysiology of dentate granule cells after kainate-induced synaptic reorganization of the mossy fibers. Brain Res 573:305-310.

Davies CH, Starkey SJ, Pozza MF, Collingridge GL (1991) GABAB autoreceptors regulate the induction of LTP. Nature 349:609-611.

Decker MW, McGaugh JL (1991) The role of interactions between the cholinergic system and other neuromodulatory systems in learning and memory. Synapse 7:151-168.

Derrick BE, Weinberger SB, Martinez JL Jr (1991) Opioid receptors are involved in an NMDA receptor-independent mechanism of LTP induction at hippocampal mossy fiber-CA3 synapses. Brain Res Bull 27:219-223.
Derrick BE, Rodriguez SB, Lieberman DN, Martinez JL Jr (1992) Mu opioid receptors are associated with the induction of hippocampal mossy fiber long-term potentiation. J Pharmacol Exp Ther 263:725733.

Drake CT, Terman GW, Simmons ML, Milner TA, Kunkel DD, Schwartzkroin PA, Chavkin C (in press) Dynorphin opioids present in dentate granule cells may function as retrograde inhibitory neurotransmitters. J Neurosci, in press.

Frey U, Schroede H, Matthies H (1990) Dopaminergic antagonists prevent long-term maintenance of posttetanic LTP in the CA1 region of rat hippocampal slices. Brain Res 522:69-75.

Gall C, Brecha N, Karten HJ, Chang K-J (1981) Localization of enkephalin-like immunoreactivity to identified axonal and neuronal populations of the rat hippocampus. J Comp Neurol 198:335-350.

Gallagher M, King RA, Young NB (1983) Opiate antagonists improve spatial memory. Science 221:975-976.

Gallagher M, Bostock E, King R (1985) Effects of opiate antagonists on spatial memory in young and aged rats. Behav Neural Biol 44: 374-385.

Grover LM, Teyler TJ (1990) Two components of long-term potentiation induced by different patterns of afferent activation. Nature $347: 477-479$.

Hanse E, Gustafsson B (1992) Long-term potentiation and field EPSPs in the lateral and medial perforant paths in the dentate gyrus in vitro: a comparison. Eur J Neurosci 4:1191-1201.

Harris EW, Ganong AH, Cotman CW (1984) Long-term potentiation in the hippocampus involves activation of $N$-methyl-D-aspartate receptors. Brain Res 323:132-137.

Hays WL (1973) Statistics for the social sciences. New York: Holt, Rinehart and Winston.

Hopkins WF, Johnston D (1984) Frequency-dependent noradrenergic modulation of long-term potentiation in the hippocampus. Science 236:350-351.

Houser CR, Miyashiro JE, Schwartz BE, Walsh GO, Rich JR, DelgadoEscueta AV (1990) Altered patterns of dynorphin immunoreactivity suggest mossy fiber reorganization in human hippocampal epilepsy. J Neurosci 10:267-282.

Huang YY, Malenka RC (1993) Examination of TEA-induced synaptic enhancement in area CAl of the hippocampus: the role of voltage-dependent $\mathrm{CA}^{2+}$ channels in the induction of LTP. J Neurosci 13:568-576.

Ishihara K, Katsuki H, Sugimura M, Kaneko S, Satoh M (1990) Different drug-susceptibilities of long-term potentiation in three input systems to the CA3 region of the guinea pig hippocampus in vitro. Neuropharmacology 29:487-492.

Jiang HK, Owyang V, Hang JS, Gallagher M (1989) Elevated dynorphin in the hippocampal formation of aged rats: relation to cognitive impairment on a spatial learning task. Proc Natl Acad Sci USA 86: $2948-2951$.

Jones LS (1991) Naloxone blocks antiepileptogenic properties of an in vitro electroconvulsive shock model. Brain Res 564:336-340.

Kauer JA, Malenka RC, Nicoll RA (1988) NMDA application potentiates synaptic transmission in the hippocampus. Nature 334:250252.

I ee HK, Dunwiddie T, Hoffer B (1980) Electrophysiological interactions of enkephalins with neuronal circuitry in the rat hippocampus. II. Effects on interneuronal excitability. Brain Res 184:331-342.

Lee KS (1982) Sustained enhancement of evoked potentials following brief high-frequency electrical stimulation of the cerebral cortex in vitro. Brain Res 239:617-623.

Lynch MA, Clements MP, Voss KL, Bramham CR, Bliss TVP (1991) Is arachidonic acid a retrograde messenger in long-term potentiation? Biochem Soc Trans 19:391-396.

Martin MR (1983) Naloxone and long term potentiation of hippocampal CA3 field potentials in vitro. Neuropeptides 4:45-50.

Masukawa LM, Prince DA (1982) Enkephalin inhibition of inhibitory input to $\mathrm{CA} 1$ and $\mathrm{CA} 3$ pyramidal neurons in the hippocampus. Brain Res 249:271-280.

McCraugh JI. (1989) Involvement of hormonal and neuromodulatory systems in the regulation of memory storage. Annu Rev Neurosci 12: 255-287.

McGinty JF, Henriksen SJ, Goldstein A, Terenius L, Bloom FE (1983) Dynorphin is contained within hippocampal mossy fibers: immunochemical alterations after kainic acid administration and colchicine-induced neurotoxicity. Proc Natl Acad Sci USA 80:589-593.

McGinty JF, Van Der Kooy A, Bloom FE (1984) The distribution 
and morphology of opioid peptide immunoreactive neurons in the cerebral cortex of rats. J Neurosci 4:1104-1117.

McLean S, Rothman RB, Jacobson AE, Rice KC, Herkenham M (1987) Distribution of opiate receptor subtypes and enkephalin and dynorphin immunoreactivity in the hippocampus of squirrel, guinea pig, rat and hamster. J Comp Neurol 255:497-510.

Messing RB, Jensen RA, Martinez JL, Spiehler VR, Vasquez BJ, Soumireu-Mourat B, Liang KC, McGaugh JL (1979) Naloxone enhancement of memory. Behav Neural Biol 27:266-275.

Morris RGM (1989) Synaptic plasticity and learning: selective impairment of learning in rats and blockade of long-term potentiation in vivo by the $N$-methyl-D-aspartate receptor antagonist AP5. J Neurosci 9:3040-3057.

Morisett RA, Mott DD, Lewis DV, Swartzwelder HS, Wilson WA (1991) $\mathrm{GABA}_{\mathrm{B}}$-receptor-mediated inhibition of the $N$-methyl-D-aspartate component of synaptic transmission in the rat hippocampus. J Neurosci 11:203-209.

Morris RGM, Anderson E, Lynch GS, Baudry M (1986) Selective impairment of learning and blockade of long-term potentiation by an $N$-methyl-D-aspartate receptor antagonist AP5. Nature 319:774-776.

Muller D, Joly M, Lynch G (1988) Contributions of quisqualate and NMDA receptors to the induction and expression of LTP. Science 242:1694-1697.

Neumaier JF, Mailheau S, Chavkin C (1988) Opioid receptor-mediated responses in the dentate gyrus and CAl region of the rat hippocampus. J Pharmacol Exp Ther 244:564-570.

Nock B, Rajpara A, O'Connor LH, Cicero TJ (1988) Autoradiography of [ $\left.{ }^{3} \mathrm{H}\right] \mathrm{U}-69593$ binding sites in rat brain: evidence for kappa opioid receptor subtypes. Eur J Pharmacol 154:27-34.

Nock B,"Giordano L, Cicero T, O'Connor L (1990) Affinity of drugs and peptides for U-69,593-sensitive and -insensitive kappa opiate binding sites: the U-69,593-insensitive site appears to be the beta endorphin-specific epsilon receptor. J Pharmacol Exp Ther 254:412419.

Racine RJ, Milgram NW, Hafner S (1983) Long-term potentiation phenomena in rat limbic forebrain. Brain Res 260:217-231.

Satoh M, Ishihara K, Katsuki H, Sigimara M (1989) Opioidergic modulation of LTP in the guinea pig hippocampus in vitro. Adv Biosci 75:193-196.

Schuman EM, Madison DV (1991) A requirement for the intercellular messenger nitric oxide in long-term potentiation. Science 254:15031506.

Singh L, Vass CA, Hunter JC, Woodruff GN, Hughes J (1990) The anticonvulsant action of CI-977, a selective kappa-opioid receptor agonist: a possible involvement of the glycine/NMDA receptor complex. Eur J Pharmacol 191:477-480.

Sloviter RS (1992) Possible functional consequences of synaptic reorganization in the dentate gyrus of kainate-treated rats. Neurosci Lett 137:91-96.

Takemori AE, Ho BY, Naeseth JS, Portoghese PS (1988) Nor-binaltorphimine, a highly selective kappa-opioid antagonist in analgesic and receptor hinding assays. J Pharmacol Exp Ther 246:255-258

Terman GW, Wagner JJ, Schatzki A, Chavkin C (1992) Kappa opioids inhibit long-term potentiation in the dentate gyrus of the guinea pig hippocampus. Soc Neurosci Abstr 18:1372.

Tortella FC (1988) Endogenous opioid peptides and epilepsy: quieting the seizing brain? Trends Pharmacol Sci 9:366-372.

Tortella FC, Robles L, Mosberg HI, Holaday JW (1986) U50,488H, a highly selective kappa opioid: anticonvulsant profile in rats. J Pharmacol Exp Ther 237:49-53.

Tortella FC, Echevarria E, Lipkowski AW, Takemori AE, Portoghese PS, Holaday JW (1989) Selective kappa antagonist properties of nor-binaltorphimine in the rat mes seizure model. Life Sci 44:661665.

Tortella FC, Robles L, Echevarria E, Hunter JC, Hughes J (1990) PD117302, a selective non-peptide opioid kappa agonist, protects against NMDA and maximal electroshock convulsions in rats. Life Sci 46:PL1-PL7.

Wagner JJ, Caudle RM, Neumaier JF, Chavkin C (1990) Stimulation of endogenous opioid release displaces mu receptor binding in rat hippocampus. Neuroscience 37:45-53.

Wagner JJ, Evans CJ, Chavkin C (1991) Focal stimulation of the mossy fibers releases endogenous dynorphin that bind kappa 1 opioid receptors in guinea pig hippocampus. J Neurochem 57:333-343.

Wagner JJ, Caudle RM, Chavkin C (1992) Kappa opioids decrease excitatory transmission in the dentate gyrus of the guinea pig hippocampus. I Neurosci 12:132-141.

Wagner JJ, Terman GW, Chavkin C (1993) Endogenously released dynorphins inhibit synaptic transmission and modulate plasticity in the dentate gyrus of the hippocampus. Nature 363:451-454.

Weber E, Barchas JD (1983) Immunohistochemical distribution of dynorphin $\mathrm{B}$ in rat brain: relation to dynorphin $\mathrm{A}$ and alpha-neoendorphin systems. Proc Natl Acad Sci USA 80:1125-1 129.

Weisskopf MG, Zalutsky RA, Nicoll RA (1993) The opioid peptide dynorphin mediates heterosynaptic depression of hippocampal mossy fibre synapses and modulates long-term potentiation. Nature 362 : 423-427.

Wigstrom H, Gustaffson B (1984) A possible correlate of the postsynaptic condition for long-lasting potentiation in the guinea pig hippocampus in vitro. Neurosci Lett 44:327-332.

Wigstrom H, Gustaffson B (1985) On long-lasting potentiation in the hippocampus: a proposed mechanism for its dependence on coincident pre- and postsynaptic activity. Acta Physiol Scand 123:519-522.

Williams S, Johnston D (1988) Muscarinic depression of long-term potentiation in CA3 hippocampal neurons. Science 242:84-87.

Xie CW, Lewis DV (1991) Opioid-mediated facilitation of long-term potentiation at the lateral perforant path-dentate granule cell synapse. J Pharmacol Exp Ther 256:289-296.

Zieglgansberger W, French ED, Siggins GR, Bloom FE (1979) Opioid peptides may excite hippocampal pyramidal neurons by inhibiting adjacent inhibitory interneurons. Science 205:415-417.

Zukin R, Eghbali M, Olive D, Unterwald E, Tempel A (1988) Characterization and visualization of rat and guinea pig kappa opioid receptors: evidence for $\kappa_{1}$ and $\kappa_{2}$ opioid receptors. Proc Natl Acad Sci USA 85:4061-4065. 